\title{
PENGARUH VARIASI DIAMETER LUBANG NOZZLE TERHADAP DIMENSI DROPLET, SUDUT SPRAY, JARAK SPRAY, DAN BENTUK NYALA API BAHAN BAKAR MINYAK BIJI KAPUK
}

\author{
Mochammad Fitroh Rozaqi \\ Teknik Mesin, Fakultas Teknik \\ Universitas Maarif Hasyim Latif, Sidoarjo, Indonesia \\ e-mail : mochammad-fitroh-rozaqi@student.umaha.ac.id
}

\begin{abstract}
ABSTRAK
Beberapa tahun trakhir ini, Indonesia mulai mengalami krisis BBM (bahan bakar minyak) minyak nabati merupakan peluang besar guna untuk mempersiapkan persediaan bahan bakar alternatif di karnakan minyak nabati ini muda di temukan di indonesia. Minyak nabati menjadi penting yang dulunya exporter sekarang menjadi importir, sehingga kami memutuskan menganalisa minyak biji kapuk sebagai mana bahan bakar alternatif pengganti bahan bakar bio solar. Dan adanya pemrosesan atomisasi bahan bakar salah satunya di pengaruhi tekanan bentuk nozzle dan diameter nozzle, sehingga bahan bakar layak untuk di gunakan minyak biji kapuk memiliki sifat atimisasi yang baik sehingga bisa membentuk butiran - butiran droplet dan dapat terbakar secara sempurna, karateristik spray seperti sudut penyebaran droplet, kecepatan spray dan ukuran droplet yang sudah ditribusikan, suda di tentukan pada proses atomisasi yang terjadi. Sehingga minyak biji kapuk perlu di analisa dengan cara melakukan penelitian tentang pengaruh variasi lubang nozzle dengan berbabagai macam diameter lubang nozzle $0,2 \mathrm{~mm}, 0,4 \mathrm{~mm}$ dan $0,6 \mathrm{~mm}$ dengan tekanan 50 bar yang tidak di variasikan guna untuk megetahui sudut spray dengan berbagai variasi nozzle yang sebagai mana semakin besar sudut spray maka berbanding lurus dengan besarnya diameter lubang nozzle dan diameter droplet akan menjadi besar, jika diameter lubang nozzle di perbesar. sehingga panjang nyala api menjadi besar di karnakan adanya variasi diameter lubang nozzle, jarak nyala api Flashback akan semakin dekat di karnakan diameter lubang nozzle yang di variasikan peroses pengujian ini di lakukan berkali kali hingga mendapatkan data yang maksimal.
\end{abstract}

Kata kunci: biji kapuk, droplet, flash back, nozzle, panjang nyala api, spray.

\section{PENDAHULUAN}

Beberapa tahun terakhir ini, indonesia mulai mengalami krisis bbm (bahan bakar minyak) minyak nabati merupakan peluang besar untuk bangsa indonesia. Penggunaan bioenergi sebagai energi alternatif guna untuk mempersiapkan persediaan bahan bakar alternatif yang mudah di temukan di indonesia, minyak nabati menjadi penting karna sejak tahun 2005 indonesia telah berubah yang dulunya eksportir sekarang berubah menjadi importer bbm. Ditambah lagi krisis minyak dunia sehingga harga minyak global menjadi meningkat, di karnakan bahan bakar minyak global yang semakin menipis dan perlu adanya penganti bahan bakar minyak global ya itu bahan bakar alternatif sehingga kami memutuskan meganalisa minyak biji kapuk yang sebagai mana itu bahan bakar alternatif adanya pemerosesan atomisasi bahan bakar salah satunya di pengaruhi tekanan, betuk nozzle dan diameter nozzle.

sehingga bahan bakar yang layak di gunakan kalaupun bahan bakar tersebut memiliki sifat atimisasi yang baik sehingga bisa membentuk butiran-butiran droplet daoat menghasilkan pembakaran yang sempurnah. Karateristik spray sepeti sudut penyebaran droplet, kecepatan spray dan ukuran droplet yang suda distribusikan, yang suda di tentukan pada proses atomisasi yang terjadi.

Minyak biji kapuk sebagai bahan yang akan di uji dengan cara mengambil data, sudut spray, mengetahui besar butiran dimensi droplet, panjang nyala api, dilanjut penelitian yang terakhir ya itu flashback nyala api.

\section{METODE PENELITIAN}

Berikut penelitian ini akan mengunakan metode experimental pada bahan yang akan di gunakan penelitian adalah minyak biji kapuk dengan alat simulasi seperti pembakaran pada mesin diesel. Alat yang akan digunakan adalah pompa bertekanan 150 bar di sambung ke selang menuju pressure lalu ke diameter lubang nozzle ditaruh pada dudukan meja instalasi berikut adallah gambar instalasi tersebut. 


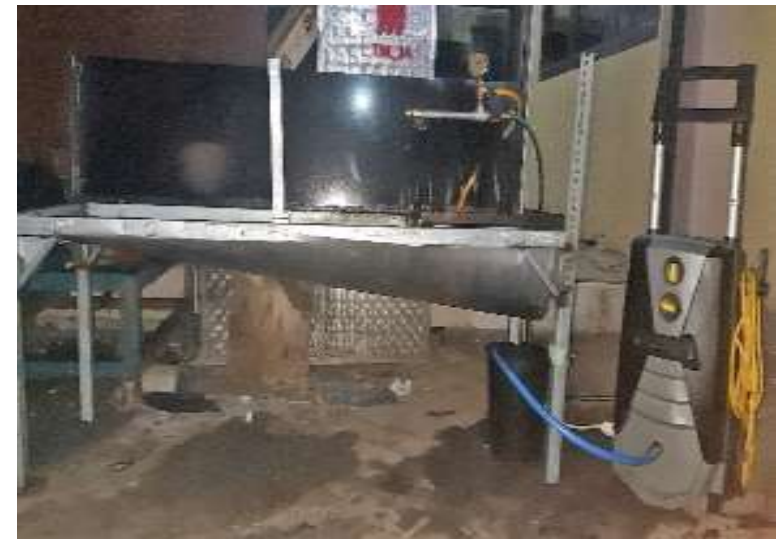

Gambar 1. Instalasi alat pengambilan data.

Pada gambar di atas adalah instalasi pengambilan data sudut spray, besar dimensi droplet, panjang nyala api, flashback nyala api. Dengan variasi diameter lubang nozzle 0,2 mm, 0,4 mm, 0,6 mm, dan tekanan yang tidak di variasikan ya itu 50 bar dengan bahan yang akan di ujikan adalah minyak biji kapuk. Pengambilan data menggunakan kamera cannon $1100 \mathrm{~d}$, hasil data yang berupa video akan di pecah menjadi gambar jpg denggan menggunakan aplikasi software free video to jpg converter, image j, steleah itu gambar di edit dengan aplikasi corel draw.

Dalam proses penelitian dibutuhkan sistematika penyelesaian yang baik untuk memudahkan pengerjaan perencanaan flowchart dibawah ini:

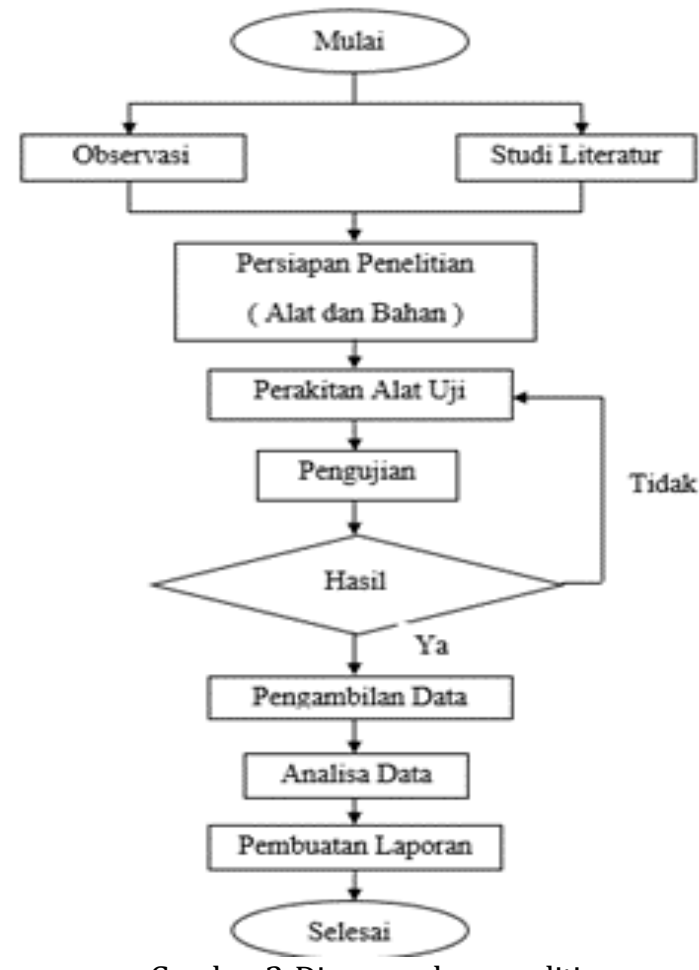

Gambar 2. Diagram alur penelitian

Gambar di atas menunjukan langkah-langka alur penelitian yang akan di lakukan dan alat yang perlu di siapkan adalah:

1. Jet cleaner tekanan 150 bar
2. Selang jalur masuk jet cleaner

3. Ember plastik, untuk tempat minyak

4. Meja instalasi

5. Selang jalur ke nozzle

6. Baypas valve

7. Pressure

8. Nozzle

9. Penggaris (mistar)

Langkah- langkah alur penelitian

Alur penelitia di bagi menjadi 9 di karnakan banyak yang harus di lakukan ya itu:

1. literature adalah yang inggin memeca permasalah yang di hadapi, seperti jurnal, buku teks, penelitian dan lain-lain, hal ini dimaksudkan untuk memperoleh data teknis mengenai segala hal yang berhubungan dengan penelitian pengaruh variasi diameter lubang nozzle terhadap dimensi droplet, sudut spray, jarak nyala api, dan Flashback nyala api bahan bakar alternatif minyak biji kapuk.

2. Survei dilakukan dengan cara mensurvei bahan bakar biodiesel minyak biji kapuk yang di proleh dari CV. Gaja mada pandaan malang yang akan dijadikan bahan dasar dari metode penelitian. serta mengamati kararteristik minyak biji kapuk baik dalam data maupun wujud fisik.

3. Yang paling di utamakan adalah pada saat kita melakukan pengujian maka harus mempersiap kan alat-alat yang di butuhka pada saat melalukan pengujian.

4. Perakitan alat-alat yang di butuhkan agar dapat mengambil data yang sempurna mungkin.

5. Setelah perakitan alat uji pembakaran selesai maka akan dilakukan analisa pembakaran bahan bakar minyak biji kapuk guna untuk mengambil data data yang relevan akan digunakan dalam pengujian sudut spray, droplet. panjang nyala api, flashback nyala api.

6. Hasil pengambilan data yang suda di lakunan, akan di ulang lagi jika pengambilan data tersebut kurang sampai menemukan hasil yang sempurnah.

7. Pengambilan data dari penelitian ini baik secara data visual maupun data tertulis.

8. Setelah data sudah di proleh maka adanya analisa data dari bahan bakar minyak biji kapuk di ambil datanya yang terbaik dari minyak ntersebut.

9. Karna suda dapat data yang terbaik dari hasil analisa data maka di lanjut denggan mebuat data laporan secara detail dari hasil penelitian.

\section{HASIL DAN PEMBAHASAN}

Berikut pembahasan hasil pengambilan data minyak biji kapuk, dengan cara pengujian spray dengan berbagai 4(empat) pengujia ya itu. Panjang nyala api, sudut penyebaran droplet, flashback nyala api dan dimensi dropelt berbagai posisi dengan lubang nozzle yang divarsikan. Nozzle yang akan di ujikan adalah variasi lubang nozzle 0,2 $\mathrm{mm} 0,4 \mathrm{~mm}$ dan $0,6 \mathrm{~mm}$, 
Variable tetap pada pengujian sudut spray pada variasi lubang nozzle dari pompa bahan bakar bertekanan 50 bar.

Kecepatan Injeksi Bahan Bakar

Guna untuk pengambilan data yang akan di butuhkan sebagai berikut:

1. Diameter variasi lubang nozzle: 0,2 $\mathrm{mm} 0,4 \mathrm{~mm} \mathrm{0,6} \mathrm{mm}$

2. Tekana sudut spray pada nozzle: 50 bar

Data yang akan di ambil guna untuk mengetauhi sudut, kecepatan injeksi diameter droplet, waktu dan debit sehingga di perlukan pencapaian droplet paling jauh. Sebagai berikut merupakan data bahan bakar minyak biji kapuk :
1. Densitas
$: 974$
2. Visikositsas kenimatik
$: 45,55$
3. Tegangan permukaan
: $34 \mathrm{Ns} / \mathrm{n}$

Berikut adalah kecepatan bahan bakar yang dapat di perkirakan denggan menggunakan rumus persamaan (liguang,2000).

Perhitungan kecepatan :

$$
\begin{aligned}
\text { Diketahui : } & \mathrm{C}_{\mathrm{d}} \quad=0,65 \\
\rho_{\mathrm{L}}= & 974 \mathrm{Kg} / \mathrm{m}^{2} \\
\Delta \mathrm{p}_{\text {inj } 1}= & 50 \mathrm{Bar}= \\
& =5.000 .000 \mathrm{~kg} / \mathrm{ms}^{2} \\
= & 5.10^{6} \mathrm{~kg} / \mathrm{ms}^{2}
\end{aligned}
$$

Ditanya $=\mathrm{V}_{\text {inj............? }}$

Jawaban

$$
\begin{aligned}
\mathrm{V}_{\text {inj } 1=}=\mathrm{C}_{\mathrm{d}} \sqrt{\frac{2 . \Delta p i}{\rho l}} \\
=0,65 \sqrt{\frac{2.5 \cdot 10^{6} \mathrm{~kg} / \mathrm{ms}^{2}}{974 \mathrm{~kg} / \mathrm{ms}^{3}}} \\
=0,65 \sqrt{\frac{2.5 \cdot 10^{6} \mathrm{~kg} \cdot \mathrm{m}^{3}}{974 \mathrm{~kg} \cdot \mathrm{ms}^{2}}} \\
=0,65 \sqrt{\frac{10.000 \cdot 000 \mathrm{~kg} \cdot \mathrm{s}^{3}}{974 \mathrm{~kg} / \mathrm{ms}^{2}}} \\
=0,65 \sqrt{10266 \cdot 91 \mathrm{~m}^{2} / \mathrm{s}^{2}} \\
=0,65 \cdot 101 \cdot 32 \mathrm{~m} / \mathrm{s} \\
=65 \cdot 858 \mathrm{~m} / \mathrm{s}
\end{aligned}
$$

Tekanan terhadap nozzle tidak di variasikan maka diasumsikan pada setiap diameter nozzle sama yaitu sebesar $65,858 \mathrm{~m} / \mathrm{s}$ sehingga sesui angka yang di tentukan secara teoritis.

\section{Debit Bahan Bakar}

kecepatan semprotan bahan bakar suda di ketahui secara teoritis maka untuk mengetahui debit bahan bakar dapat di tentukan menggunakan rumus pesamaan

Berikut:

$$
Q=A . v
$$

Maka :

$$
\begin{aligned}
\mathrm{A}_{1}=\frac{3,14}{4} \cdot(0,2)^{2} \\
\mathrm{~A}_{1}=0,031 \mathrm{~m}^{2} \\
v_{i}=65,85 \mathrm{~m} / \mathrm{s}
\end{aligned}
$$

Sehingga nilai debit bahan bakar pada nozzle 0,2 mm adalah :

$$
\begin{aligned}
& \mathrm{Q}_{1}=\mathrm{A} . \mathrm{V} \\
& =0,031 \mathrm{~m}^{2} \cdot 65.85 \mathrm{~m} / \mathrm{s} \\
& =2.04 \mathrm{~m}^{3} / \mathrm{s} \\
& \text { Diket } \quad \rho=936 \mathrm{~kg} / \mathrm{m}^{3} \\
& \mathrm{Q}=0,31 \mathrm{~m}^{3} / \mathrm{s} \\
& \text { Ditanya ...........? } \\
& \text { Jawaban } \\
& \dot{\mathrm{m}}_{1}=\rho \cdot \mathrm{Q}_{1} \\
& =974 \mathrm{~kg} / \mathrm{m}^{3} .2,04 \mathrm{~m}^{3} / \mathrm{s} \\
& =1986,96 \mathrm{~kg} / \mathrm{s}
\end{aligned}
$$

\section{Rumus Perhitungan Sudut Secara Teoritis}

Sudut spray dapat di hitung secara teoritis, untuk mengetahui besar sudut penyebaran droplet maka dapat di prkirakan perhitungkan besar droplet sebagai brikut:

$$
\begin{aligned}
\theta=0,05\left(\frac{\Delta \mathrm{p}_{\mathrm{i}} \mathrm{d}_{\mathrm{o}}^{2}}{\rho_{l} v_{l}^{2}}\right)^{1 / 4} & \\
\text { Dimana: } & \\
\Delta \mathrm{p}_{\mathrm{i}} & =50 \mathrm{bar} \\
& =5 \times 10^{6} \mathrm{~kg} / \mathrm{ms}^{2} \\
\mathrm{~d}_{\mathrm{o}} & =0,2 \mathrm{~mm} \\
\rho_{l} & =974 \mathrm{~kg} / \mathrm{m}^{3} \\
v_{l} & =45,55 \mathrm{~mm}^{2} / \mathrm{s}
\end{aligned}
$$

Sehingga besar sudut penyebaran droplet secara teoritis adalah :

$$
\begin{aligned}
& \theta_{1}=0,05\left(\frac{\Delta p i \cdot d^{2}}{\rho l \cdot \mu v}\right)^{1 / 4} \\
& =0.05\left(\frac{5 \cdot 10^{6} \mathrm{~kg} / \mathrm{ms}^{2} \cdot(0,2 \mathrm{~mm})^{2}}{974 \mathrm{~kg} / \mathrm{m}^{3} \cdot\left(45,55 \mathrm{~mm}^{2} / \mathrm{s}\right)^{2}}\right)^{1 / 4} \\
& =0.05\left(\frac{5 \cdot 10^{6} \mathrm{~kg} / \mathrm{ms}^{2} \cdot(0,04 \mathrm{~mm})^{2}}{974 \mathrm{~kg} / \mathrm{m}^{3} \cdot\left(2074 \cdot 802 \mathrm{~mm}^{2} / \mathrm{s}\right)^{2}}\right)^{1 / 4} \\
& =0.05\left(\frac{5 \cdot 10^{6} \mathrm{~kg} / \mathrm{ms}^{2} \cdot 4 \cdot 10^{-8} \mathrm{~m}^{2}}{974 \mathrm{~kg} / \mathrm{m}^{3} \cdot 2074 \cdot 8 \cdot 10^{-12} \mathrm{~m}^{4} / \mathrm{s}^{2}}\right)^{1 / 4} \\
& =0.05\left(\frac{5.10^{6} \cdot 4 \cdot 10^{-8} \cdot 10^{12}}{974 \cdot 2074 \cdot 8}\right)^{1 / 4} \\
& =0.05\left(\frac{20 \cdot 10^{10}}{2020855 \cdot 2}\right)^{1 / 4} \\
& =0,05(98968)^{1 / 4} \\
& =0,05.17,736 \\
& \theta_{1}=0,886
\end{aligned}
$$

Jadi $\operatorname{arc} \tan 0,886=41,54^{\circ}$

Jadi perhitungan sudut sudut spray dengan menggunakan nozzle $0,2 \mathrm{~mm}$ menghasilkan besar sudut $41,54^{\circ}$ denggan tekanan yang tidak di variasikan dan diameter nozzle di variasikan maka secara teoritis sudut penyebaran droplet yang terbentuk mengalami peningkatan pada saat diameter droplet diperbesar. 


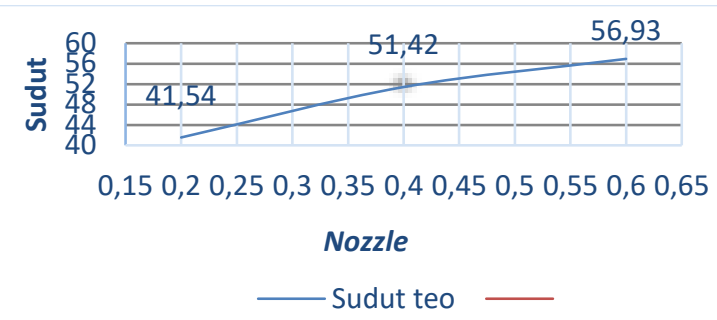

Gambar 3. Grafik pengertian tentang pengaruh lubang nozzle terhadap penyebaran droplet

\section{Pengambilan Data Droplet}

Di karnakan keterbatasan alat untuk mengukur droplet secara actual, maka untuk mengetahui besar butiran droplet yang terbentuk hasil dari atomisasi bahan bakar dapat diperkirakan menggunakan persamaan Sauter Mean Diameter atau $\mathrm{D}_{32}$ berikut :

$\mathrm{D}_{32}=4.12 \mathrm{~d}_{\mathrm{n}} R e^{0,12} W e^{-0,75}\left\{\frac{\mu_{f}}{\mu_{a}}\right\}^{0,54}\left\{\frac{\rho_{f}}{\rho_{a}}\right\}^{0,18}$

Agar persamaan diatas bisa ditentukan nilainya maka harus ditentukan terlebih dahulu nilai Reynolds number (Re) spray dan Weber number (We) droplet. Dimana nilai Reynolds number dapat ditentukan menggunakan persamaan :

$R e_{\text {sprayy }}=\frac{\mathrm{v}_{f} d_{n}}{v_{f}}=\frac{65,85 \mathrm{~m} / \mathrm{s} \times 0,4 \mathrm{~mm}}{45,55 \mathrm{~mm}^{2} / \mathrm{s}}=578,26$

Sedangkan nilai Weber number dapat ditentukan menggunakan rumus persamaan:

$W e_{\text {drop }}=\frac{\rho_{f} \mathrm{v}_{l}^{2} d_{n}}{\sigma_{l}}$

$$
\begin{aligned}
& =\frac{974 \mathrm{~kg} / \mathrm{m}^{3}(65,85 \mathrm{~m} / \mathrm{s})^{2} 0,4 \mathrm{~mm}}{3,4 \mathrm{~N} / \mathrm{m}} \\
& =24,844
\end{aligned}
$$

Dimana:

$$
\begin{aligned}
\sigma_{f} & =3,4 \mathrm{~N} / \mathrm{m} \\
\rho_{f} & =947 \mathrm{~kg} / \mathrm{m}^{3} \\
\rho_{a} & =1,2 \mathrm{~kg} / \mathrm{m}^{3} \\
v_{f} & =45,55 \mathrm{~mm}^{2} / \mathrm{s} \\
\mathrm{v}_{f} & =65,85 \mathrm{~m} / \mathrm{s} \\
\mathrm{d}_{\mathrm{n}} & =0,4 \mathrm{~mm} \\
\mu_{f} & =34 \mathrm{Ns} / \mathrm{m}^{2} \\
\mu_{a} & =0,89 \mathrm{Ns} / \mathrm{m}^{2}
\end{aligned}
$$

Karena nilai Reynolds number dan weber number sudah duketahui maka untuk mencari dimensi droplet adalah :

$$
\begin{gathered}
D_{32}=4,12 \times 0,4 \mathrm{~mm}(2,145)^{0,12}(0,0003)^{-0,75} \\
\left.\qquad \frac{34 \mathrm{Ns} / \mathrm{m}^{2}}{0.89 \mathrm{Ns} / \mathrm{m}^{2}}\right\}^{0,54}\left\{\frac{974 \mathrm{~kg} / \mathrm{m}^{3}}{1,2 \mathrm{~kg} / \mathrm{m}^{3}}\right\}^{0,18} \\
=25,3 \mathrm{~m} / \mathrm{s}
\end{gathered}
$$

Pada tabel bawah ini menjelaskan terjadi peningkatan diameter droplet pada setiap nozzle variasi nozzle.
Tabel 1. Perbandinggan diameter droplet terhadap variasi lubang nozzle

\begin{tabular}{|c|c|c|c|}
\hline No & Tekanan & Nozzle & Droplet \\
\hline 1 & 50 & 0,2 & 19,4 \\
\hline 2 & 50 & 0,4 & 25,3 \\
\hline 3 & 50 & 0,6 & 26,5 \\
\hline
\end{tabular}

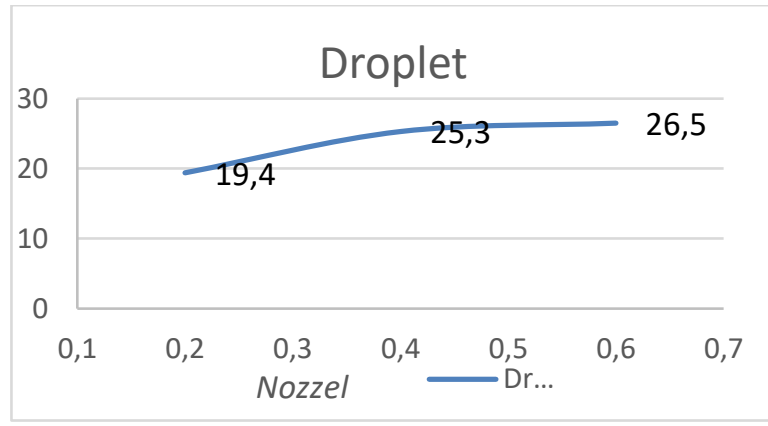

Gambar 4. Grafik hasil pengambilan data droplet sudut spray

Variasi diameter nozzle dengan menggunakan tekanan sudut ya itu 50 bar. Dan berbagai variasi nozzle sehingga semakin besar diameter nozzle di perbesar, semakin pula data yang di hasil kan menjadi besar. Sudah terlihat droplet dengan diameter nozzle 0,2 $\mathrm{mm}$ lebih kecil di bandingkan droplet diameter nozzle $0,4 \mathrm{~mm}$ dan diameter nozzle 0,6 $\mathrm{mm}$ lebih besar di bandinggan ke 2 nozzle tersebut. Besar droplet yang di hasilkan nozzle 0,2 $\mathrm{mm}$ ya itu $0,4 \mathrm{~mm}$ dan besar droplet $0,4 \mathrm{~mm}$ menghasilkan besar droplet $0,53 \mathrm{~mm}$ diameter nozzle $0,6 \mathrm{~mm}$ lebih besar ya itu $0,65 \mathrm{~mm}$ visikositas adalah kekentalan suatu fluida maka kekentalan semakin tinggi sehingga fluida sulit untuk terpecah menjadi butiran droplet.

\section{Sudut Spray}

Sebagai mana hasil pengujian sudut spray berbagai variasi ukuran nozzle $0,2 \mathrm{~mm} \mathrm{0,4} \mathrm{mm} \mathrm{0,6} \mathrm{mm} \mathrm{denggan}$ mengunakan tekaanan sudut 50 bar.

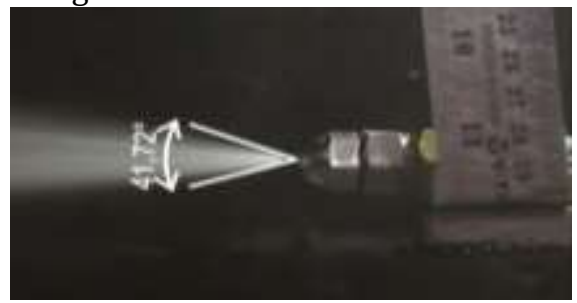

Gambar 5. Sudut spray diameter lubang nozzle 0,2 mm

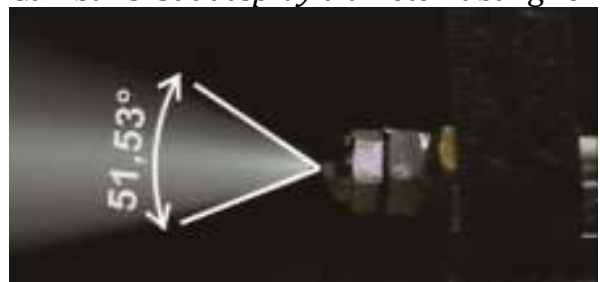

Gambar 6. Sudut spray diameter lubang nozzle 0,4 mm 


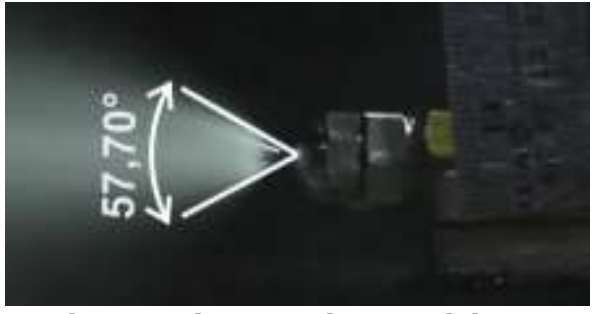

Gambar 7. Sudut spray diameter lubang nozzle 0,6 mm Hasil gambar di atas merupakan berbagai variasi penyebara droplet dengan diameter lubang nozzle, pada gambar $4.1 \quad 4.2 \quad 4.3$ Berbagai variasi tersebut menghasilkan sudut yang berbeda - beda titik semburan droplet pada lubang nozzle 0,2 $\mathrm{mm}$ lebih kecil di bandingkan lubang nozzle 0,4 $\mathrm{mm}$ dan 0,6 mm masing masing sudut mengunakan tekanan 50 bar. Pada perubahan titik semburan droplet pada lubang nozzle 0,2 mm $41,72^{\circ}$ mengalami peningkatan sudut sebesar $9,88^{\circ}$ sedangkan hasil pengambilan data pada penyebaran droplet lubang nozzle $0,4 \mathrm{~mm}$ sebesar $51,52^{\circ}$, dan sehingga penyebaran droplet lubang nozzle lebih meningkat karna diameter lubang nozzle $0,4 \mathrm{~mm}$ di perbesar menjadi $0,6 \mathrm{~mm}$ sehingga mengalami peningkatan sebesar $5,41^{\circ}$. hasil pengambilan data pada lubang nozzle $0,6 \mathrm{~mm}$ sebesar $57,70^{\circ}$ dan sehingga mengalami peningkatan sudut penyebaran droplet lubang nozzle yang bervariasi.

Tabel 2. Sudut spray sudut actual dan sudut teori

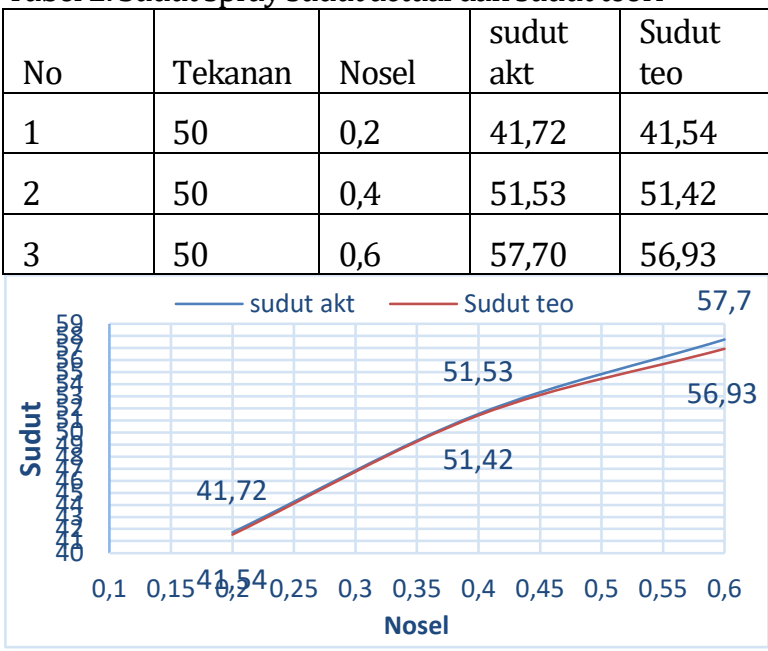

Gambar 8. Grafik Perbandingan sudut actual dengan sudut teoritis

Gambar grafik di atas menunjukan di antara lubang nozzle $0,2 \mathrm{~mm}$ lebih kecil di bandingkang lubang nozzle $0,4 \mathrm{~mm}$ dan jauh lebih kecil lagi pada saat diameter lubang nozzle di perbesar menjadi 0,6 $\mathrm{mm}$ perubahan sangat bervariasi dan sangat berpengaruh pada lubang nozzle, perubahan sudut yang di awali dengan lubang nozzle $0,2 \mathrm{~mm}$ sudut penyebaran droplet sebesar $41,70^{\circ}$ jauh lebih kecil di bandingkan diameter lubang nozzle 0,4 $\mathrm{mm}$ dan lebi kecil lagi di bandingkan lubang nozzle 0,6 $\mathrm{mm}$ dimana hasil sudut $0,4 \mathrm{~mm}$ sebesar $51,53^{\circ}$ dan nozzle di perbesar lagi diameter nozzle menjadi $0,6 \mathrm{~mm}$ sebesar $57,70^{\circ}$ dan sehingga sudut spray lebih lebih besar di bandingkan diameter lubang nozzle 0,2 $\mathrm{mm}$.
Disisi lain minyak biji kapuk juga termasuk dalam golongan minyak terlarut yang memiliki rantai panjang asam lemak dan rentan terhadap oksidasi, hal tersebut mengakibatkan nilai viskositas minyak biji kapuk menjadi tinggi. Viskositas yang tinggi pada bahan bakar minyak kapuk mengakibatkan laju aliran bahan bakar terhambat sehingga mempengaruhi besar sudut penyebaran droplet.

\section{PANJANG NYALAH API}

Pengambilan data kali ini di lanjut dengang pengambilan data panjang api dengan berbagai variasi diameter nozzle dengan tekanan yang tidak di variasikan sehingga variasi diameter nozzle dengan cara pengujian pengukuran panjang nyala api, diameter lubang nozzle $0,2 \mathrm{~mm}$ panjang nyala api lebih pendek jika di bandingkan dengan diameter lubang nozzle 0,4 mm lebih jauh lagi di bandingkan diameter lubang nozzle 0,6 mm dengan tekanan yang tidak di variasikan ya itu 50 bar.

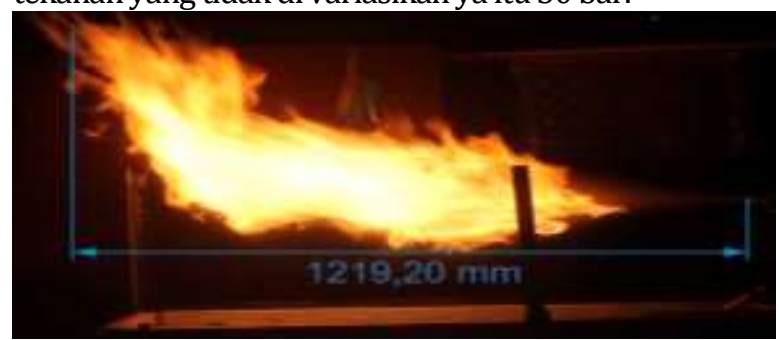

Gambar 9. Panjang nyala api diameter lubang nozzle 0,2 $\mathrm{mm}$

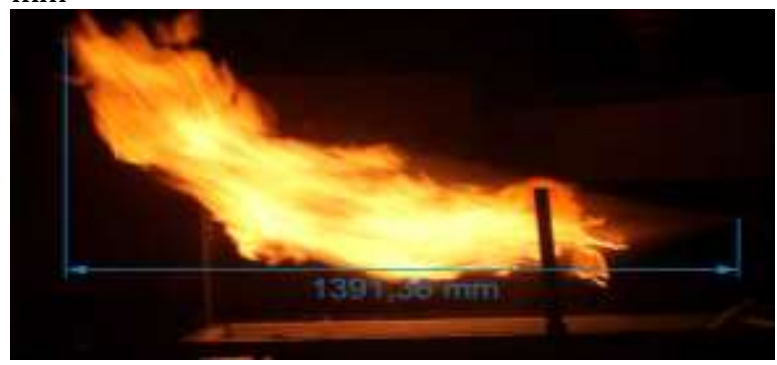

Gambar 10. Panjang nyala api diameter lubang nozzle 0,4 $\mathrm{mm}$

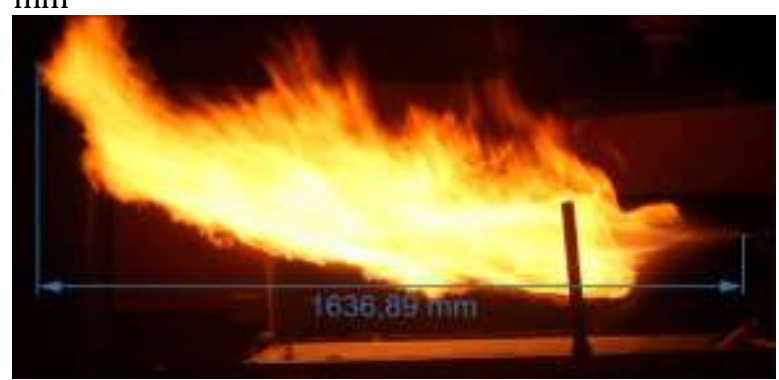

Gambar 11. Panjang nyala api diameter lubang nozzle 0,6 $\mathrm{mm}$

Hasil panjang nyala api 0,2 mm menghasilkan panjang nyalah api 1143,00 mm di bandingkan panjang nyala api 0,4 mm lebih panjang yaitu 1299,63 mm di bandingkan dengan diameter lubang nozzle 0,2 $\mathrm{mm}$ jauh lebih pendek dan jauh lebih panjang lagi jika di bandingkan dengan diameter lubang nozzle $0,6 \mathrm{~mm}$ panjang nyalah api yang terbentuk mencapai $1611,49 \mathrm{~mm}$.

Tabel 3. Panjang nyalaah api dengan variasi lubang nozzle 


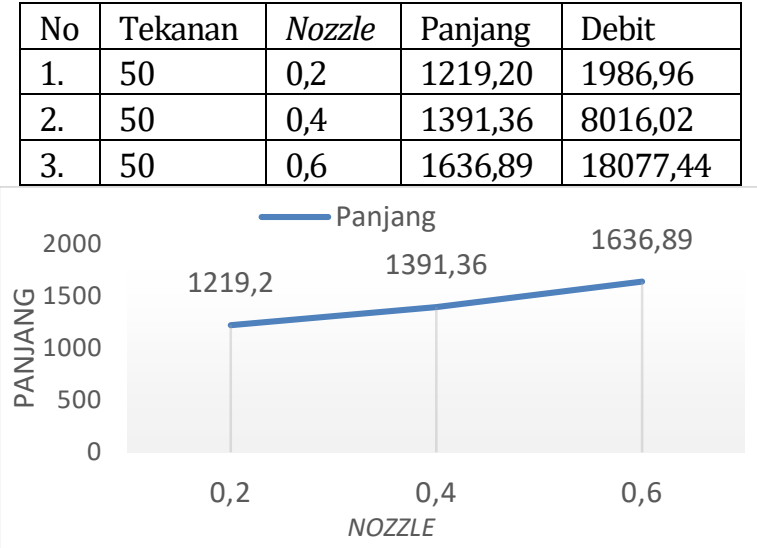

Gambar 12. Grafik jarak panjang nyala api

Pada gambar grafik di halaman 53, menjukan bahwa semakin besar diameter lubang nozzle secara tidak langsung akan mempengaruih panjang nyalah api karna adanya debit bahan bakar yang melalui lubang nozzle denggan tekanan yang tidak di variasikan yaitu 50 bar sebagai mana debit tersebut melalu lubang nozzle sebesar 1986,96 $\mathrm{m}^{3} / \mathrm{s}$ dan debit yang paling besar terjadi pada diameter nozzle $0,6 \mathrm{~mm}$ ya itu 18077,44 $\mathrm{m}^{3} / \mathrm{s}$.

Flashback nyala api pada jarak $100 \mathrm{~mm}$

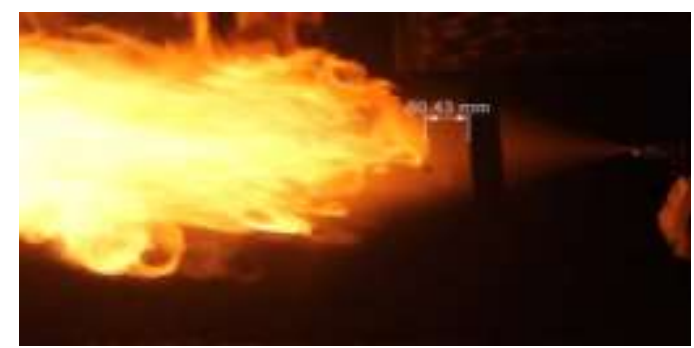

Gambar 12. Flashback nyala api diameter lubang nozzle $0,2 \mathrm{~mm}$ dengan jarak $100 \mathrm{~mm}$

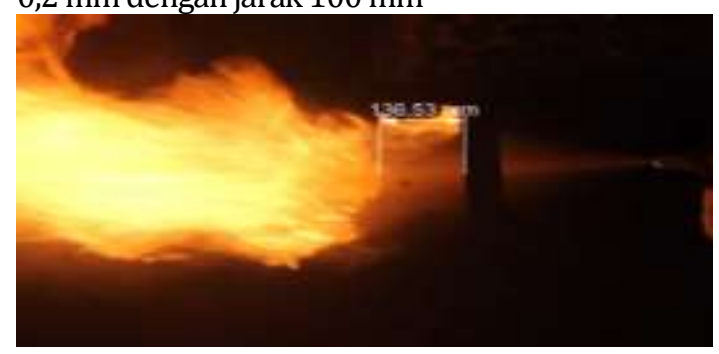

Gambar 13. Flashback nyala api diameter lubang nozzle $0,4 \mathrm{~mm}$ dengan jarak $100 \mathrm{~mm}$

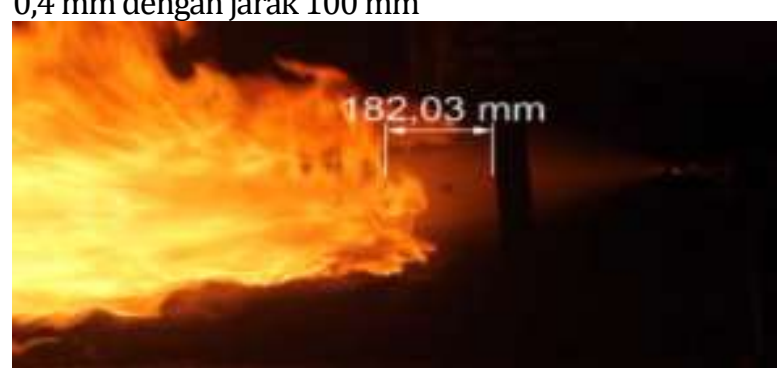

Gambar 14. Flashback nyala api diameter lubang nozzle 0,6 mm dengan jarak $100 \mathrm{~mm}$

Pada gambar di atas menunjukan bahwasanya tidak terjadi flashback pada saat pemantik api di nyalakan tepat di garis mistar berada di posisi jarak $100 \mathrm{~mm}$ sehingga menghasilkan jarak flashback yang bervariasi pada diameter nozzle $0,2 \mathrm{~mm}$ nyala api flashback menghasilkan jarak 80,43 mm dan kemudian jarak nyala api meningkat di karnakan lubang nozzle di ruba menjadi 0,4 mm peningkatan flashback nyala api menjadi 136,53 $\mathrm{mm}$ kembali lebih meningkat di karnakan diameter lubang nozzle menjadi 0,6 $\mathrm{mm}$ sehingga menghasilkan jarak 182,03 mm.

Tabel 4. Flashbacknyalah api dengan jarak 100mm

\begin{tabular}{|l|l|l|l|}
\hline \multirow{2}{*}{ No } & \multirow{2}{*}{ Tekanan } & \multirow{2}{*}{ Nozzle } & Flashback \\
\cline { 4 - 4 } & & & $100 \mathrm{~mm}$ \\
\hline 1 & 50 & 0,2 & $80,43 \mathrm{~mm}$ \\
\hline 2 & 50 & 0,4 & $136,53 \mathrm{~mm}$ \\
\hline 3 & 50 & 0,6 & $182,03 \mathrm{~mm}$ \\
\hline
\end{tabular}

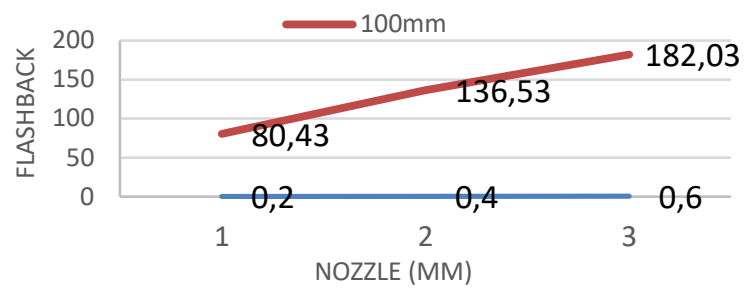

Gambar 15. Grafik falshback nyala api dengan jarak $100 \mathrm{~mm}$

Gambar grafik flashback nyala api di atas menunjukan bahwa posisi pemantik api dengan jarak $100 \mathrm{~mm}$ menuju ke depan lubang nozzle, diameter lubang nozzle menjadi meningkat di karnakan ada pengaruh terhadap variasi lubang nozzle terhadap flashback nyala api.

\section{Flashback nyala api pada jarak $500 \mathrm{~mm}$}

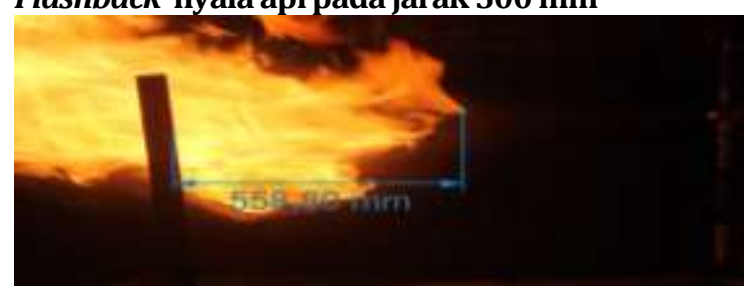

Gambar 16. Flashback nyala api diameter lubang nozzle $0,2 \mathrm{~mm}$ dengan jarak $500 \mathrm{~mm}$

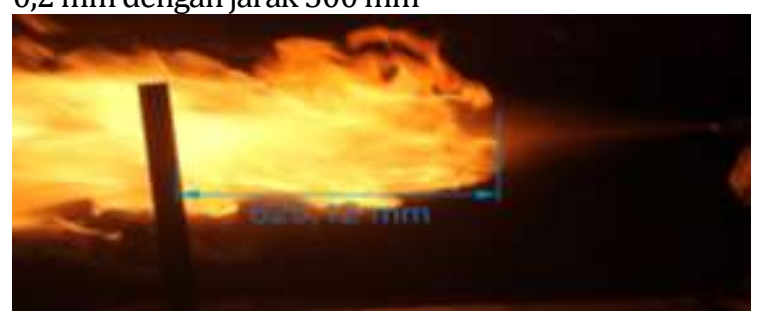

Gambar 17. Flashback nyala api diameter lubang nozzle $0,4 \mathrm{~mm}$ dengan jarak $500 \mathrm{~mm}$

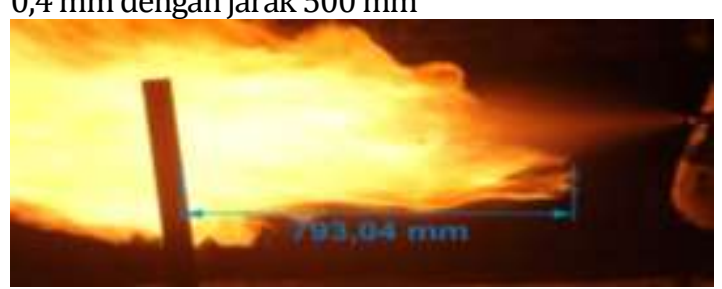

Gambar 18. Flashback nyala api diameter lubang nozzle $0,6 \mathrm{~mm}$ dengan jarak $500 \mathrm{~mm}$ 
Gambar di atas sudah menunjugkkan bahwasanya terjadinya flashback di karnakan saat pemantik api di nyalakan pas di jarak $500 \mathrm{~mm}$ yang di tandai dengan mistar seperti pada gambar di atas tersebut. Pada saat pengujian denggan menggunakan diameter nozzle 0,2 mm terjadi jarak flashback sebesar $558,80 \mathrm{~mm}$ dan flashback lebih memanjang lagi karna diameter lubang nozzle di rubah menjadi 0,4 $\mathrm{mm}$ dan sehingga menghasilkan jarak flashback sebesar 625,12 mm sedangkan pada saat diameter nozzle di perbesar lagi. Menjadi 0,6 mm hasil jarak flashback melibih hasil jarak flashback lubang nozzle 0,4 mm sehingga menghasilkan jarak flashback sebesar 793,04 mm di depan mistar. Tabel 5. Flashback nyalah api dengan jarak $500 \mathrm{~mm}$

\begin{tabular}{|c|c|c|c|}
\hline \multirow{2}{*}{ No } & \multirow{2}{*}{ Tekanan } & \multirow{2}{*}{ Nosel } & Flash back \\
\hline & & & $500 \mathrm{~mm}$ \\
\hline 1 & 50 & 0,2 & $558,8 \mathrm{~mm}$ \\
\hline 2 & 50 & 0,4 & $625,12 \mathrm{~mm}$ \\
\hline 3 & 50 & 0,6 & $793,04 \mathrm{~mm}$ \\
\hline \multirow{3}{*}{ 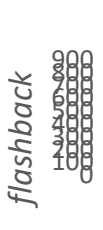 } & \multicolumn{3}{|c|}{$-500 \mathrm{~mm}$} \\
\hline & \multicolumn{3}{|c|}{$\begin{array}{lll}-558,8 & 625,12 & 793,04\end{array}$} \\
\hline & 0,2 & 0,4 & 0,6 \\
\hline \multicolumn{4}{|c|}{$(\mathrm{mm})$} \\
\hline
\end{tabular}

Gambar 18. Grafik falshback nyala api dengan jarak $500 \mathrm{~mm}$

Grafik di atas menunjukan bahwa jarak flashback dengan diameter nozzle 0,2 mm lebih rendah ya itu sebesar 558,8 mm di bandingkan flashback nyala api dengan diameter nozzle 0,4 mm menghasilkan jarak flashback sebesar $625,12 \mathrm{~mm}$ dan sehingga menjadi terus meningkat saat diameter lubang nozzle di perbesar.

\section{Flashback nyala api pada jarak $900 \mathrm{~mm}$}

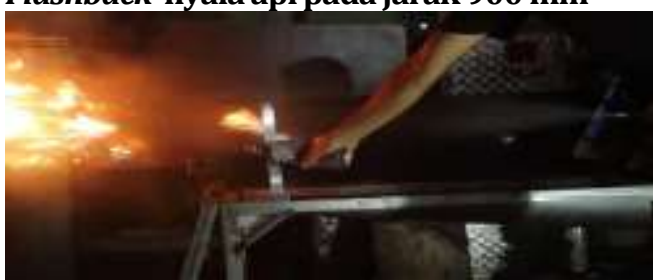

Gambar 19. Flashback nyala api diameter lubang nozzle $0,2 \mathrm{~mm}$ dengan jarak $900 \mathrm{~mm}$

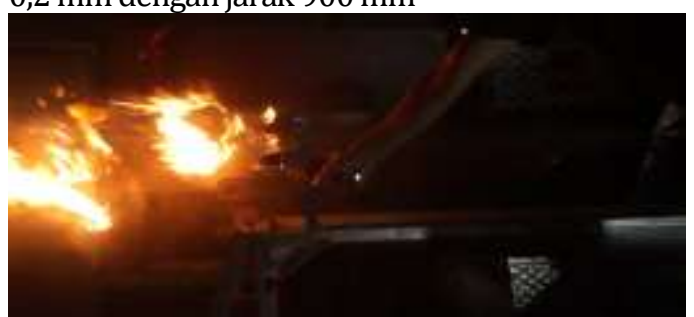

Gambar 20. Flashback nyala api diameter lubang nozzle 0,4 mm dengan jarak $900 \mathrm{~mm}$

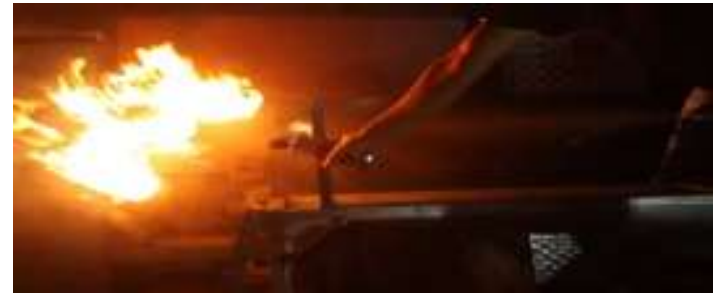

Gambar 21. Flashback nyala api diameter lubang nozzle 0,6 mm dengan jarak $900 \mathrm{~mm}$

Berikut gambar di atas menunjukan pada saat pemantik api di nyalakan dan di arahkan ke mistar dengan jarak 900 $\mathrm{mm}$ semburan droplet dari ujung nozzle, bahan bakar tidak dapat menyala di karnakan tidak setabil. Pada saat diameter nozzle $0,2 \mathrm{~mm} 0,4 \mathrm{~mm}$ dan $0,6 \mathrm{~mm}$ hanya terjadi titik nyala api kecil tidak bisa merambat ke ujung nozzle. Di karnakan kurang nya butiran" droplet tersebut.

\section{PENUTUP}

1. Variasi diameter lubang nozzel $0,2 \mathrm{~mm}, 0,4 \mathrm{~mm}$ dan 0,6 mm dengan tekanan 50 bar berbanding lurus dengan dimensi droplet yang mana semakin besar diameter lubang nozzle, maka semaknin besar dimeni droplet yang di hasilkan seperti halnya diameter lubang nozzle 0,6 $\mathrm{mm}$ yang menghasilkan besar dimensi droplet 26,5 $\mathrm{m} / \mathrm{s}$ lebih besar di bandingkan diameter lubang nozzle $0,2 \mathrm{~mm}$ yang menghasilkan dimensi droplet $19,4 \mathrm{~m} / \mathrm{s}$.

2. Semakin besar sudut spray maka berbanding lurus dengan diameter lubang nozzle yang di variasikan sehingga besar diameter lubang nozzle $0,2 \mathrm{~mm}$ sebesar $41,72^{\circ}$ sudut spray yang di hasilkan lebih kecil di bandingkan diameter lubang nozzle $0,6 \mathrm{~mm}$ yang menghasilkan $57,70^{\circ}$ dan sehingga diameter lubang nozzle $0,4 \mathrm{~mm}$ lebih dominan ya itu sebesar $51,53^{\circ}$.

3. Besar diameter lubang nozzel maka semakin besar jarak nyala api yang di hasilkan pada diameter lubang nozzle 0,6 mm sebesar 1636,89 $\mathrm{mm}$ di bandingkan diameter lubang nozzle 0,2 mm yang menghasilkan 1219,20 mm lebih kecil dan lebih dominan diameter lubang nozzle 0,4 mm sebesar 1391,36 mm.

4. Berbagai flashback dengan diameter lubang nozzle $0,2 \mathrm{~mm} \mathrm{0,4} \mathrm{mm} \mathrm{0,6} \mathrm{mm} \mathrm{dengan} \mathrm{tekanan}$ yang tidak di variasikan ya itu sebesar 50 bar dengan jarak yang bervariasi jarak yang di gunakan $100 \mathrm{~mm}, 500 \mathrm{~mm}, 900 \mathrm{~mm}$ sehingga menghasilakan nilai flashback yang bebedabeda. Jarak $100 \mathrm{~mm}$ dengan diameter lubang nozzle 0,2 $\mathrm{mm}$ menghasilkan nilai flashback sebesar $80,43 \mathrm{~mm}$ sedangkan diameter lubang nozzle 0,2 $\mathrm{mm}$ dengan jarak $500 \mathrm{~mm}$ sebesar $558,8 \mathrm{~mm}$ pada saat pengambilan data dengan jarak $900 \mathrm{~mm}$ pada saat pemantik api di nyalakan di bagaian pas di garis mistar, tidak terjadi pembakaran di karnakan jarak yang 
terlalu jauh di karnakan kurang nya semburan droplet.

\section{UCAPAN TERIMA KASIH}

Terimakasi kepada seluruh dosen umaha teknik mesin khusus nya kepada dosen pembimbing (ir. H. Eddy gunawan, $\mathrm{mt}$ ) atas bimbingan dan saran yang di berikan sehingga kami dapat menyelesaikan penelitian ini pada tepat waktu, serta teman - teman dan keluarga atas dukungan nya.

\section{DAFTAR PUSTAKA}

Andaka. (2008). Biji kapuk mengandung minyak yang dapat diambil dan dimanfaatkan sebagai produk yang bernilai tinggi. Penyusun utama minyak biji kapuk adalah trigliserida.

Afifah, Y. N. (2016). ALIRAN TAK TUNAK FLUIDA NANO MAGNETOHIDRODINAMIK ( MHD) YANG MELEWATI BOLA.

Afifah, Y. N., \& Putra, B. C. (2018). Model Matematika Aliran Tak Tunak Pada Nano Fluid Melewati Bola Teriris Dengan Pengaruh Medan Magnet. Teknika: Engineering and Sains Journal, 2(2), 119-124.

Afifah, Y. N. (2019). Analysis of Unsteady Magneto Hydro Dynamic ( MHD) Nano Fluid Flow Past A Sliced Sphere Analysis of Unsteady Magneto Hydro Dynamic ( MHD ) Nano Fluid Flow Past A Sliced Sphere. IOP Conference Series: Materials Science and Engineering, 494, 012033. https://doi.org/10.1088/1757899X/494/1/012033

De Stefano dkk. (2008). Spray yang dihasilkan dipengaruhi oleh tekanan air yang diberikan. Pada tekanan tinggi, hubungan antara ukuran droplet dan tekanan akan menjadi lebih kompleks.Biasanya terjadi penurunan diameter secara signifikan dengan meningkatnya tekanan.

Edi Mulyadi. (2011). Biodiesel dapat diaplikasikan secara langsung untuk mesin diesel tanpa melalui modifikasi terlebih dahulu dan memiliki kelebihan lain dibandingkan dengan solar, tidak beracun, karena biodiesel tidak mengandung sulfur serta senyawa aromatik, sehingga.

Erliza, dkk. (2007). Di samping itu biodiesel memiliki angka setan lebih tinggi (>57), memiliki sifat pelumasan terhadap piston mesin dan dapat terurai (biodegradable), merupakan renewable energy karena terbuat dari bahan alam yang dapat diperbaharui, serta meningkatkan indep.

F.G Winarno. (2002). Minyak merupakan bahan cair pada suhu ruang disebabkan tingginya kandungan asam lemak yang tidak jenuh, yang memiliki satu atau lebih ikatan rangkap diantara atom-atom karbonnya, sehingga mempunyai titik lebur yang rendah.

Gunawan, E. et al. (2019) 'Analysis of the Effect of Current Flow Variations in GTAW on SS 400 Plate Material Connected with SUS 304 Stainless Steel Plate Against Tensile Strength and Hardness with ER308L Electrodes', Journal of Physics: Conference Series, 1175(1). doi: 10.1088/1742-6596/1175/1/012277.

Haryono \& Marlani. (2014). Salah satu sumber energi hayati potensial di indonesia adalah minyak biji kapuk (ceiba pentadra ). Minyak biji kapuk ini mengandung asam lemak tidak jenuh sekitar 63,27\%, dengan kadar asam lemak bebas sekitar 8,6\%.

Julianus. (2006). Pada reaksi transesterifikasi ini, sebagai reaktan dapat digunakan metanol atau etanol. Pada proses ini dipilih metanol sebagai reaktan karena merupakan alkohol yang paling reaktif. Reaksi transesterifikasi merupakan reaksi yang bersifat reversible. Karen.

Liu, Gong, Li, Wang, \& Yu. (2006). Ketika droplet hasil pengkabutan berukuran lebih besar maka lebih sedikit bahan bakar yang berhasil terbakar sehingga lebih banyak bahan bakar sisa yang tidak terbakar.

N. A. Chigier and C. G. McCreath. (1974). Ada beberapa parameter penting yang terlibat dalam pembakaran semprot termasuk komposisi bahan bakar, ukuran tetesan, komposisi gas dan suhu, kecepatan relatif antara tetesan dan udara dan tekanan pembakaran.

Putra, B. C., \& Afifah, Y. N. (2018). Gaussian Mixture Model Untuk Penghitungan Tingkat. Teknika: Engineering and Sains Journal, 2, 53-58.

Yunita Nur Afifah, MNH Qomarudin and Imamatul Ummah (2020) 'Optimal Control Model Pemanenan Prey-Predator di Area Konservasi Ikan', Buana Matematika : Jurnal Ilmiah Matematika dan Pendidikan Matematika, 10(1), pp. 1-16. doi: 10.36456/buanamatematika.v10i1.2410. 